\title{
Three Postulates That Change Knowledge Management Paradigm
}

\author{
Michel Grundstein \\ MG Conseil, Nogent sur Marne, LAMSADE Paris Dauphine University, Paris
}

France

\section{Introduction}

In the foreword of the book untitled "The New Age in Knowledge" (O'Dell and Hubert 2011) Larry Prusak describes some of the main principles focused on knowledge management at the beginning days (p. xi): i) Knowledge is a fixed pool, a collection of resources that can be measured and used by standard management techniques; ii) Technology is the key tool to unlock the value of this resource - more technology, the better; and iii) Individuals are the critical unit of analysis in working with knowledge - the more productive the individual is the more knowledge is being used. He concludes: "It is now clear in hindsight that these principles were developed with information in mind, not knowledge, and that they were not at all suitable to working with such elusive intangible. It is because of these ideas that many knowledge management efforts ran into problems and that the whole subject began to fade in the minds of busy executives."

However, although it does not always get the expected outcomes when put at work in organizations, the positivist paradigm of $\mathrm{KM}$, influenced by computer science and information technology, is the most implicitly recognized paradigm by researchers and practitioners in KM. From our viewpoint, this paradigm needs to be enlarged to a general view resting on a constructivist paradigm.

In this chapter we put down background theory and assumptions; notably, we introduce the concept of "commensurability of interpretative frameworks," and we propose an empirical model (DITEK) that attempts to describe the transformation process from data to information and from information to tacit and explicit knowledge. Then, we suggest a constructivist paradigm of KM within organizations based on three fundamental postulates. This leads to envisage new KM perspectives that induce specific KM Governance, and leads towards a technological, managerial, and socio-technical well-balanced KM approach within organizations referring to general model for knowledge management within organization so called MGKME. Finally, we sketch out the architecture of an enterprise's information and knowledge system (EIKS), and we propose a well-balanced KM initiative strategy within organizations.

\section{Background theory and assumptions}

\subsection{Research motivations, method, and objectives}

Our research follows a constructivist paradigm that is deeply rooted in our pragmatic experience in the real field. As a practitioner having to manage deployment of innovative 
technologies (such as computer aided design, knowledge based systems, and others) in large companies just when these technologies were conceived into universities and laboratories, we observed that we always needed to elaborate a model with socio-technical perspectives, which could be used as a pattern of reference for all stakeholders in order to engender the essential learning process that leads people to appropriate and use these technologies. Later on, when becoming Associate Researcher in the domain of KM, we perceived the lack of general model of KM that integrates socio-technical perspectives. This point of view is often disregarded when considering the technical approach of KM, although hundred of frameworks can be found in the literature (CEN-CWA 14924-1, 2004). As a practitioner we always had to consider the constructivist paradigm that underlies the creation of knowledge, and consequently KM approach. As a researcher we always had to be confronted with the positivist paradigm that most often considers knowledge independently of its links with action, and the context of organizations. Thus, our researches, notably in the domain of KM, are continuously oriented towards a well-balanced use of positivist and constructivist paradigms within organizations.

\subsection{The dominant positivist paradigm of $\mathrm{KM}$}

Numerous authors analyzed the notions of data, information and knowledge. Let us quote notably Davenport and Prusak (1998, pp.1-6), Sena and Shani (1999), Takeuchi and Nonaka, (2000), Amin and Cohendet, (2004, pp. 17-30), Laudon and Laudon, (2006, p. 416). Besides, Snowden (2000,) makes the following synthesis: "The developing practice of knowledge management has seen two different approaches to definition; one arises from information management and sees knowledge as some higher-level order of information, often expressed as a triangle progressing from data, through information and knowledge, to the apex of wisdom. Knowledge here is seen as a thing or entity that can be managed and distributed through advanced use of technology...The second approach sees the problem from a sociological basis. These definitions see knowledge as a human capability to act (pp. 241-242)."

The dominant positivism paradigm of KM is implicit in the DIKW (Data-InformationKnowledge-Wisdom) hierarchy model. This model induced numerous computers and information researches. For example, (Rowley, 2007) revisiting the DIKW hierarchy by examining the articulation of the hierarchy in a number of widely read textbooks in information systems and knowledge management preferably published in 2003 and later, noted that "there is a consensus that data, information and knowledge are to be defined in terms of one another, although data and information can both act as inputs to knowledge; the tangle of concepts can be explored at two levels - the relationship between data and information, and the relationship between information and knowledge p.174);" and she raised the question: "Is there a sharp divide between data, information and knowledge, or do they lie on a continuum with different levels of meaning, structure and actionability occurring at different levels (p. 175)."

More recently, (Muller and Maasdorp 2011) point out the dominance of the DIK model in information science. They have three conjectures as to why knowledge management practitioners and authors prefer the DIK model. The first one concerns information theory background, the second one is about simplicity, and the third one rests on accumulative worldview. Their ideas are closely akin to ours. Let's quote some of their conjunctures: "the first possible explanation for the dominance of the DIK model in KM is that it is an effect of background in information theory or communication theory of the practitioner or the 
author; the second conjecture is that simplicity counts in management and that this has the effect of privileging a theoretical position that is clearly linked to a working and productive legacy in information system but more importantly, clears up the messy situation of exactly understanding the notion of knowledge in organizations; the third conjecture is painted on an even broader canvas. If one has a worldview that is cumulative and sees the world as consisting of innumerable little bits (now not in the technical sense) of matter that all add up to the while by the process of accumulation and simple organization and categorization, then a data information knowledge model would make sense...That means that a mechanistic and positivist worldview is to be found at the base of the easy acceptance of the DIK model."

In fact, we think that, beyond all these studies, we have to position our thoughts in the contextual field where the notion of data, information, and knowledge are used: in our case, the field of enterprises and more generally organizations. That leads to conceive how the transformation process should be envisaged using the concept of commensurability of interpretative frameworks highlighted by (Tsuchiya 1993).

\subsection{The concept of commensurability of interpretative frameworks 2.3.1 Creation of Individual's tacit knowledge}

Our approach is built upon the assumption emphasized by Tsuchiya concerning knowledge creation ability. He states, "Although terms 'datum', 'information', and 'knowledge' are often used interchangeably, there exists a clear distinction among them. When datum is sense-given through interpretative framework, it becomes information, and when information is sense-read through interpretative framework, it becomes knowledge (p.88)". In other words, we can say that tacit knowledge that resides in our brain results from the sense given, through our interpretative frameworks, to data that we perceive among the information transmitted to us. Or rather, Knowledge exists in the interaction between an Interpretative Framework (incorporated within the head of an individual, or embedded into an artifact), and data.

In a different way, Wiig (2004) who highlights a discontinuity between information and knowledge describes this process clearly. He states, "The process, by which we develop new knowledge, uses prior knowledge to make sense of the new information and, once accepted for inclusion, internalizes the new insights by linking with prior knowledge. Hence, the new knowledge is as much a function of prior knowledge as it is of received inputs. A discontinuity is thus created between the received information inputs and the resulting new knowledge (p. 73)."

Consequently, we postulate that knowledge is not an object processed independently of the person who has to act. So, we can say that formalized and codified knowledge that are independent from individual, are not more than information. Furthermore, as emphasized by Haeckel (2000) we must discern "the knowledge of knower and the codification of that knowledge (p. 295)."

\subsubsection{Conditions for considering information as knowledge}

Tsuchiya emphases how organizational knowledge is created through dialogue, and highlighted how "commensurability" of the interpretative frameworks of the organization's members is indispensable for an organization to create organizational knowledge for decision and action (ref. Fig. 1). Here, commensurability is the common space of the set of interpretative frameworks of each member (e.g. cognitive models or mental models directly 
forged by education, experience, beliefs, and value systems). Tsuchiya states "It is important to clearly distinguish between sharing information and sharing knowledge. Information becomes knowledge only when it is sense-read through the interpretative framework of the receiver. Any information inconsistent with his interpretative framework is not perceived in most cases. Therefore, commensurability of interpretative frameworks of members is indispensable for individual knowledge to be shared (p. 89)."

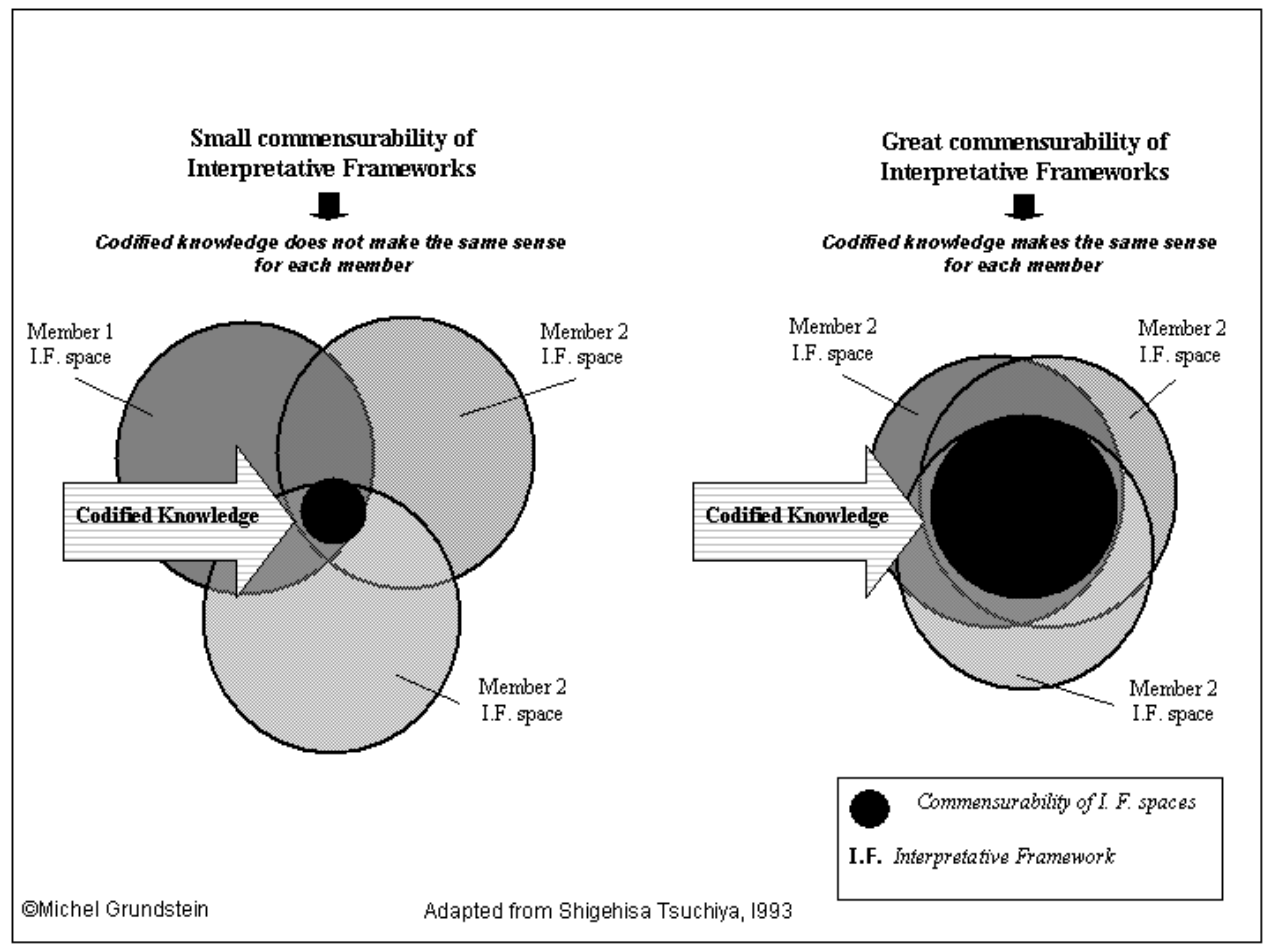

Fig. 1. Commensurability of Interpretative Frameworks (I.F.) and Individual Sense-Making

Consequently, information can only be assimilated to knowledge when members having a large commensurability of their set of interpretative frameworks commonly understand it in the same way. In that case, we call it "information source of knowledge for someone." Such is the case for members having the same technical or scientific education, or members having the same business culture. In these cases, formalized and codified knowledge make the same sense for each member; that enables to speak of knowledge bases, and flows of knowledge. However, one must take into account that interpretative frameworks evolve in a dynamic way: they are not rigid mindsets. Especially, when considering that, as time is going on, contexts and situations evolve. Thus, the contribution of scientific results, techniques and new methods, the influence of young generations being born with Web (Y generation or Digital Native), the impact of identity crisis and multiple cultures, modify the interpretative frameworks, and create a gap between individuals' commensurability of interpretative frameworks. 


\section{From data to information, and tacit and explicit knowledge: The DITEK process model}

Relying to the theories and assumptions set out above, we elaborated a model that attempt to describe the transformation process from data to information, and from information to tacit and explicit knowledge. This model, called DITEK process model, describes at a first level the relationship between data and information, and at a second level the relationship between information, and tacit and explicit knowledge (ref. Fig. 2 and Fig. 3). Contrary to the idea of continuum between the concepts of data, information, and knowledge induced by the DIKW hierarchical model, DITEK process model shows a discontinuity between these concepts.

At a first level, we have to consider the relationship between data and information. This level must be thought as a basic process where data are discrete raw elements perceived, gathered, and filtered by a person before to be aggregated, supplemented, and organized into information (ref. Fig. 2).

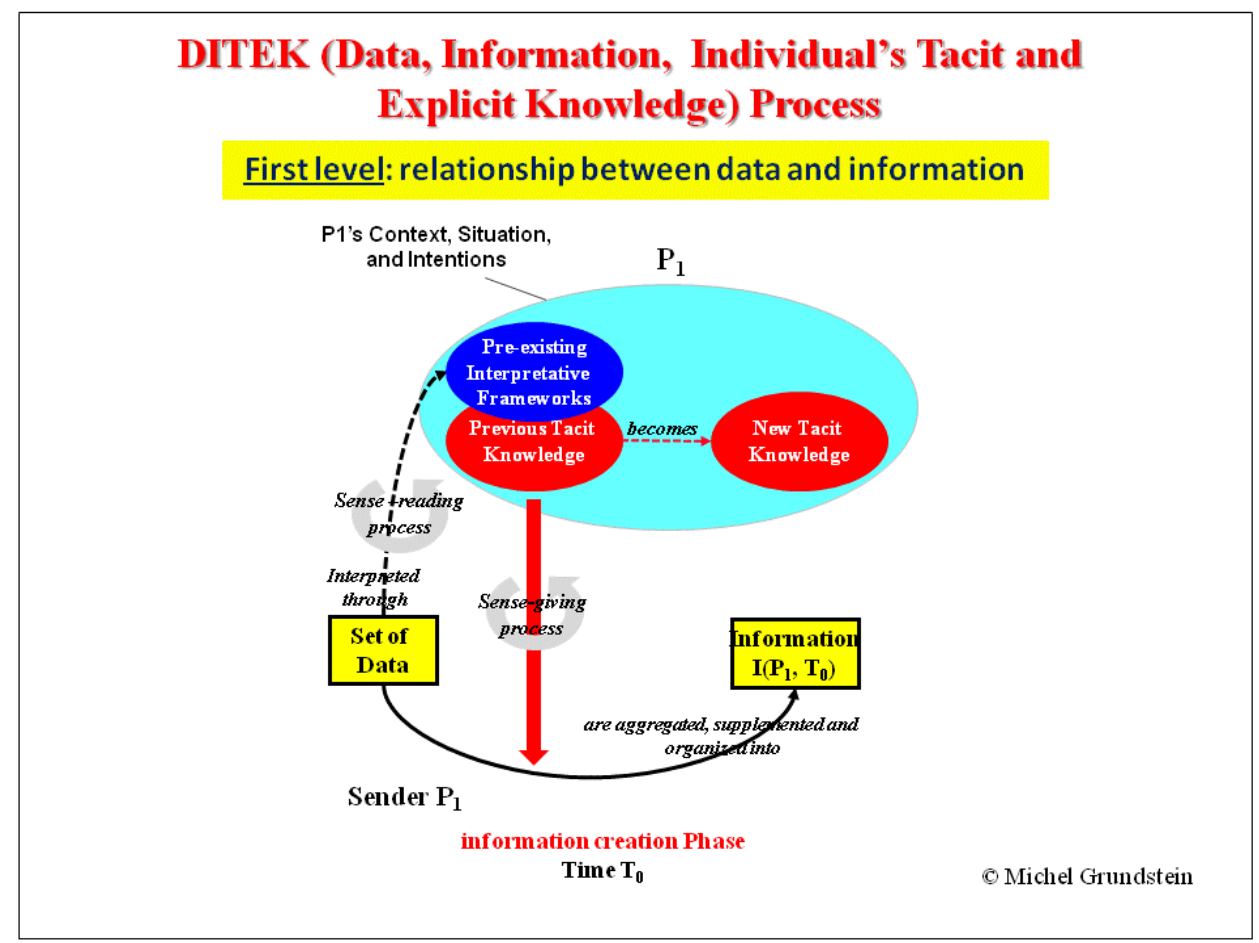

Fig. 2. DITEK process model level 1: From data...to information

At a second level, we have to consider the relationship between information, and tacit and explicit knowledge. This level is in rupture with the first one, it presupposes that information already exists whatever are time and context in which it was created. Let's describe the transformation process.

A sender $P_{1}$ is acting in specific context and situation at time $T_{0}, P_{1}$ has pre-existing interpretative frameworks, previous tacit knowledge, and intentions. In an information 
creation phase, $\mathrm{P}_{1}$, has direct access to a set of data outside himself. Then, $\mathrm{P}_{1}$ according to a sense-reading process - that depends of his pre-existing interpretative frameworks activated depending of his context, his situation, and his intentions, filters some of these data that take sense for him. At the same time, a sense-giving process using $\mathrm{P}_{1}$ 's previous tacit knowledge enables $\mathrm{P}_{1}$ to aggregate, supplement and organize selected data into information $\mathrm{I}\left(\mathrm{P}_{1}, \mathrm{~T}_{0}\right)$. Once created this information becomes a static object independent from $\mathrm{P}_{1}$, and time. It is this information that is passed-on by the individuals or by means of the digital information system (DIS) where it is stored, treated and transmitted as a stream of digital data. During this process, $\mathrm{P}_{1}$ 's pre-existing interpretative frameworks are not changing; previous tacit knowledge can be reorganized and modified into new tacit knowledge.

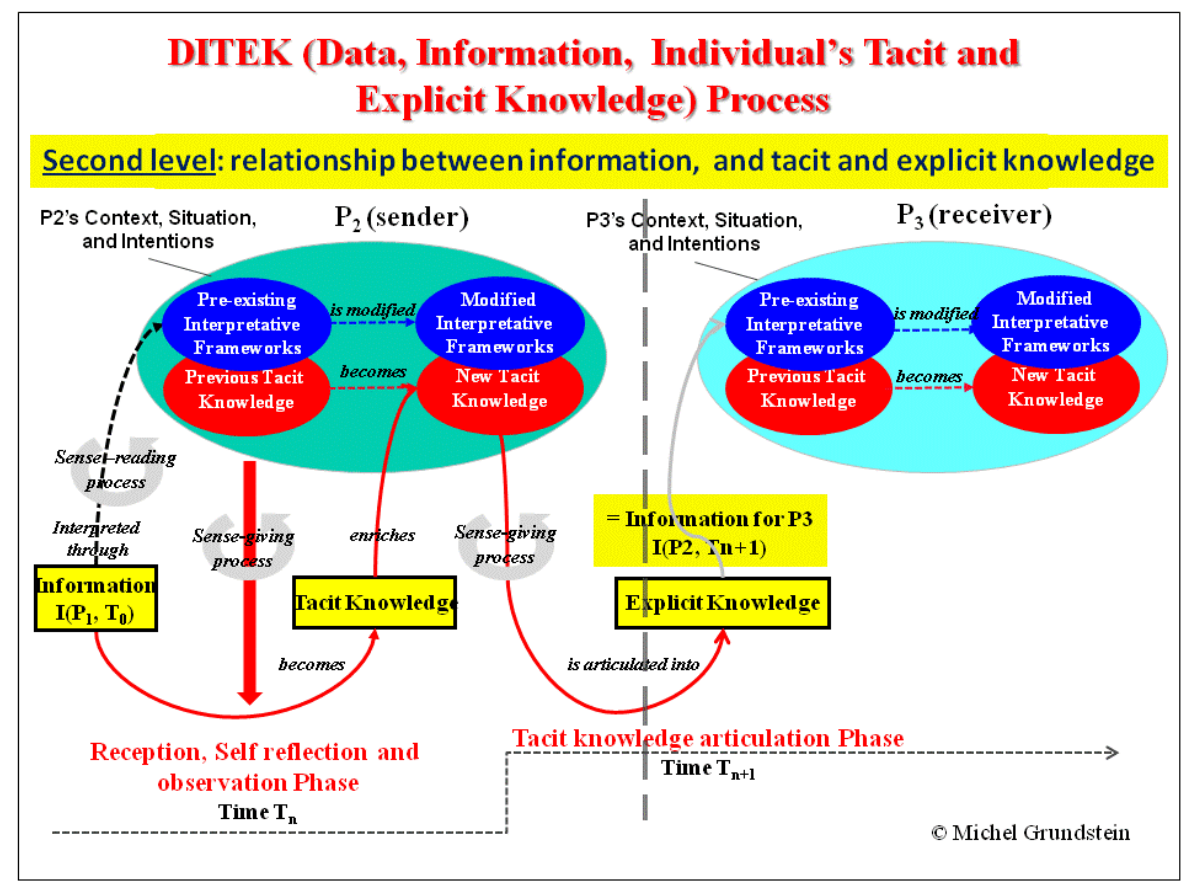

Fig. 3. DITEK process model level 2: From information...to tacit and explicit knowledge

At a later stage of the first level process, at time $T_{n}$, when $P_{2}$ perceives the information $\mathrm{I}\left(\mathrm{P}_{1}, \mathrm{~T}_{0}\right)$ during a reception, self-reflection and observation phase, this information $\left(\mathrm{P}_{1}, \mathrm{~T}_{0}\right)$ is captured by $\mathrm{P}_{2}$, who is in different context and situation than $\mathrm{P}_{1}$ who elaborates it. $\mathrm{P}_{2}$ has his own intentions. Then, $\mathrm{P}_{2}$ according to a sense-reading process, interprets this information $\left(\mathrm{P}_{1}, \mathrm{~T}_{0}\right)$, filtering data through his pre-existing interpretative frameworks activated depending of his context, his situation, and his intentions. At the same time, a sense-giving process that uses $\mathrm{P}_{2}$ 's previous knowledge operates, and engenders new tacit knowledge. That's the way that changes $P_{2}$ 's pre-existing interpretative frameworks, and enriches $P_{2}$ 's previous tacit knowledge enabling $\mathrm{P}_{2}$ to understand his situation, identify a problem, find a solution, decide, and act. The results of this process are modified interpretative frameworks, and new tacit knowledge. 
The process of transformation of information into tacit knowledge is a process of construction of knowledge. Created knowledge, can be very different from one individual to another when the commensurability of their interpretative frameworks is small, whatever are the causes of it. There are large risks that the same information takes different senses for each of them, and consequently generates a construction of different tacit knowledge in the head of the decision process stakeholders. Unlike the information, knowledge is dynamic. Once constructed it cannot be considered as an object independent from the individual who built it, or the individual who appropriates it to make a decision and to act.

Later on, at time $T_{n+1}$, when $P_{2}$ as a sender communicates with a receiver $P_{3}$, during $a$ tacit knowledge articulation phase, a sense-giving process enables $\mathrm{P}_{2}$ to articulate a part of his new tacit knowledge into explicit knowledge that is no more than information $I\left(P_{2}, T_{n+1}\right)$ for $P_{3}$.

As a result one can understand the importance to clearly distinguish static factual information, which allows describing the context and the situation that raise a problem, from the tacit knowledge of the individual who processes this information to learn and get knowledge he needs to carry out his tasks.

Consequently, paraphrasing (Kautz and Kjaergaard 2008) if technology provides the possibility of making information available across time and space (p. 49), we always have to keep in mind the role of individual in the knowledge sharing process, but we do also pay attention to how individual uses technology to share knowledge (p. 43).

Our approach is inspired by a KM constructivist paradigm. It induces to consider tacit and explicit knowledge as the outcome of a sense-giving process that involves people engaged in actions, and mainly depend of the organizational context. It implies three fundamental postulates and leads to a definition a KM focused on activities and processes opening on Technological, Managerial, and Socio-technical Well-balanced KM Initiative Strategies within Organizations

\section{A constructivist paradigm of $\mathrm{KM}$}

\subsection{Three fundamental postulates}

Our observations and experiments within the industry, led us to set forth three postulates: (i) Knowledge is not an object; (ii) Knowledge is linked to the action, and (iii) Company's knowledge includes two main categories of knowledge. We define these postulates below.

\subsubsection{Postulate 1: Knowledge is not an object}

Knowledge exists in the interaction between an interpretative Framework (incorporated within the head of an individual, or embedded into an artifact), and data. This postulate comes from the assumption emphasized by Tsuchiya (1993) concerning tacit knowledge creation ability.

\subsubsection{Postulate 2: Knowledge is linked to the action}

From an organization perspective, knowledge is created through action. Knowledge is essential for the functioning of support, and value-adding processes (Porter, 1985). Activities contributing to these processes utilize and create knowledge. Thus, the actions finalize the organization's knowledge. This viewpoint takes into account the context and the situation, which allow utilizing and creating knowledge. In particular, we must analyze the role and intentions of the actors - decision-makers - involved with these activities in order to achieve 
the organization's missions. Therefore, knowledge is linked to their decisions, their actions, and their relations with the surrounding systems (people and artifacts).

4.1.3 Postulate 3: Company's knowledge includes two main categories of knowledge Within organizations, knowledge consists of two main categories (ref.Table.1).

\begin{tabular}{|c|c|c|}
\hline $\begin{array}{l}\text { EXPLICITED KNOWLEDGE } \\
\text { (KNOW-HOW) }\end{array}$ & \multicolumn{2}{|c|}{$\begin{array}{l}\text { TACIT KNOWLEDGE EMBODIED BY INDIVIDUALS } \\
\text { (SKILLS) }\end{array}$} \\
\hline $\begin{array}{c}\text { Collective knowledge } \\
\text { (Knowledge that can be } \\
\text { though as objects) }\end{array}$ & $\begin{array}{l}\text { Collective knowledge } \\
\text { (Routines) }\end{array}$ & $\begin{array}{l}\text { Personal knowledge } \\
\text { (Private knowledge) }\end{array}$ \\
\hline $\begin{array}{l}\text { - Knowledge formalized within } \\
\text { documents and/or codified in } \\
\text { knowledge-based systems and } \\
\text { databases. } \\
\text { - Knowledge embedded in } \\
\text { automated management } \\
\text { systems, conception systems, } \\
\text { production systems, and } \\
\text { products. }\end{array}$ & $\begin{array}{l}\text { - Knowledge incorporated } \\
\text { within models, and regular } \\
\text { and predictable behaviors. }\end{array}$ & $\begin{array}{l}\text { - People's abilities, } \\
\text { - Professional knack, } \\
\text { - Knowledge of company } \\
\text { history, and decisional } \\
\text { contexts, } \\
\text { - Knowledge of the } \\
\text { environment (customers, } \\
\text { competitors, technologies), } \\
\text { and socio-economic factors }\end{array}$ \\
\hline $\begin{array}{l}\text { Information source of } \\
\text { knowledge for someone }\end{array}$ & $\begin{array}{l}\text { Defensive Routines } \\
\text { - Knowledge that is an } \\
\text { obstacle to change } \\
\text { Constructive Routines } \\
\text { - Knowledge that favors } \\
\text { innovation and change }\end{array}$ & $\begin{array}{l}\text { Specific knowledge } \\
\text { belonging to each } \\
\text { individual } \\
\text { - Knowledge that is a volatile } \\
\text { intangible resource, which } \\
\text { depends on the continuity of } \\
\text { the presence of employees in } \\
\text { the company }\end{array}$ \\
\hline
\end{tabular}

Table 1. The two main Categories of Company's knowledge

On the one hand, explicited knowledge includes all tangible elements (we call it "knowhow"); and on the other hand, tacit knowledge (Polanyi, 1966), includes intangible elements (we call it "skills"). Tacit knowledge can or cannot be articulated into explicit knowledge. The tangible elements are collective knowledge. They take the shape of formalized and codified knowledge in a physical format (databases, procedures, plans, models, algorithms, and analysis and synthesis documents), or are embedded into automated management systems, in conception and production systems, and in products. The intangible elements are inherent to the individuals who bear them, either as collective knowledge - the "routines" that are non-written individual or collective action procedures (Nelson and Winter, 1982) or personal knowledge (skills, crafts, "job secrets", historical and contextual knowledge of environment, clients, competitors, technologies, and socio-economic factors).

\subsection{Knowledge management perspectives}

Relying to the postulates mentioned above, it appears that, KM addresses activities, which utilize and create knowledge more than knowledge by itself. With regard to this question, 
since 2001, our group of research has adopted the following definition of KM (Grundstein and Rosenthal-Sabroux, 2003):

"KM is the management of the activities and the processes that enhance the utilization and the creation of knowledge within an organization, according to two strongly interlinked goals, and their underlying economic and strategic dimensions, organizational dimensions, socio-cultural dimensions, and technological dimensions: (i) a patrimony goal, and (ii) a sustainable innovation goal" (p.980).

The patrimony goal has to do with the preservation of knowledge, their reuse and their actualization; it is a static goal. The sustainable innovation goal is more dynamic. It is concerned with organizational learning that is creation and integration of knowledge at the organizational level.

This definition of KM induces a specific KM governance, and leads towards a technological, managerial, and socio-technical well-balanced KM initiatives within organizations referring to general model for knowledge management within organization so called MGKME (Grundstein, 2005a, 2007, 2008), which integrates managerial guiding principles, ad hoc infrastructures, socio-technical environment, support and value adding processes, organizational learning processes, generic KM processes, and relevant methods and supporting tools. MGKME is described section 6. Furthermore, distinguishing information from knowledge leads to conceive what we call Enterprise's Information and Knowledge Systems (EIKS).

\section{Knowledge management governance}

After having considered the Corporate Governance and the Information Technology Governance concepts, we attempt to tackle with a Knowledge Management Governance perspective drawing a link with the Corporate and IT Governance principles.

\subsection{The OECD corporate governance}

OECD (Organization for Economic Co-operation and Development) corporate governance principles were originally issued in 1999. They have since become the international benchmark for corporate governance. OECD governments in April 2004 agreed the new Principles, and define Corporate Governance as shown on figure 4 (OECD, 2004, p.11).

\subsection{The COBIT ${ }^{\circledR}$ IT Governance}

Control Objectives for Information and related Technology (COBIT $\left.{ }^{\circledR}, 2000,2002,2005\right)$ was initially published by the Information Systems Audit and Control Foundation, Inc. in 1996. Guldentops (2004) states that “COBIT ${ }^{\circledR}$ presents an international and generally accepted IT control framework enabling organizations to implement an IT Governance structure throughout the enterprise" (p. 277). A fourth edition has been edited in 2005. In the Executive Summary IT Governance is defined as shown on figure 4 (COBIT ${ }^{\circledR}, 2005$, p.6).

IT governance provides the structure that links IT process, IT resources and information to enterprise strategies and objectives. To achieve success, corporate governance and IT governance can no longer be considered separate and distinct disciplines. The COBIT ${ }^{\circledR}$ Management Guidelines helps to support these needs. They have identified specific Critical Success Factors, Key Goal Indicators, Key Performance Indicators and an associated Maturity Model for IT Governance. 


\subsection{KM Governance Perspectives}

Corporate Governance and IT Governance do not explicitly mention to consider Intellectual Capital as a resource in the enterprise strategies. Even so, as pointed out by Edvinsson and Malone (1997), "The core of the so-called knowledge economy is huge investment flows into human capital as well as information technology" (p. 12). However, we think that the knowledge economy will oblige to take into account Intellectual Capital. Consequently, we need to study the link between KM, and Corporate Governance and IT Governance. To enable such a study, we must refer to a KM pattern of reference to elaborate $\mathrm{KM}$ Governance principles.

\subsubsection{Towards a unified KM pattern of reference}

Despite the fact that numerous Knowledge Management Frameworks have been suggested all over the world, it does not exist a unify pattern of reference supporting our definition of $\mathrm{KM}$ as described in the paragraph 4.2. For example, let us consider The European Guide to Good Practice in Knowledge Management (CEN-CWA 14924-1, 2004). The project team has collected, categorized and analyzed more than 140 KM Frameworks. We can notice that this work has produced a high-quality practical outcome that is a reference point to achieve a good understanding of KM. Nevertheless, as contributors to this project, we underline the predominant positivist paradigm, and the information management approach of KM that have inspired the project team. Moreover, we have observed that few of them were "peoplefocused" as Wiig (2004) states: "our emphasis is on people and their behaviors and roles in enterprise operations (p. XXV)." Furthermore, we have distinguished two main approaches underlying KM: (i) a technological approach that answers a demand of solutions based on the technologies of information and communication (ICT); (ii) a managerial approach that integrates knowledge as resources contributing to the implementation of the strategic vision of the company.

Therefore, we suggest two KM Governance Perspectives depending on the first or the second approach (ref. Fig. 4).

On the one hand, the technological approach leads to reduce knowledge to codified knowledge that is no more than information. In that case, we can manage KM projects in the same way than IS projects. Specific criteria inherent to KMS must connect KM Governance and IT Governance principles. On the other hand, the managerial approach that integrates knowledge as a resource focuses on the core business processes and the people. Corporate Governance principles must integrate the risks linked to the utilization and creation of knowledge

These aspects involve elaborating Management Governance Guidelines for KM as COBIT ${ }^{\circledR}$ is for IT. The aim of the Model for General Knowledge Management within the Enterprise (MGKME), described hereafter, is to contribute to elaborating a guiding framework that serves as a pattern for KM Governance Guidelines.

\section{MGKME, A Model for General Knowledge Management within the Enterprise}

\subsection{KM Empirical Model versus KM System}

$\mathrm{KM}$ becomes a reality in the implementation of a system. The purpose of this system is to amplify the utilization and the creation of knowledge to improve the enterprise's effectiveness. This system is often called Knowledge Management System (KMS). Therefore, 


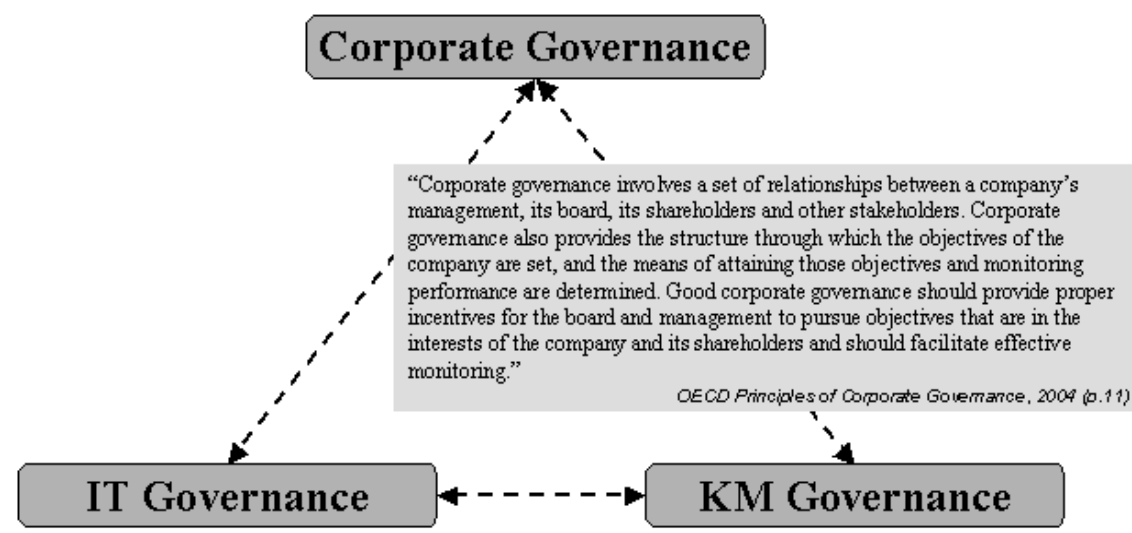

"IT govemance is the responsibility of executives and the board of directors, and consists of the leadership, organizational structures and processes that ensure that the enterprise's IT sustains and extends the organization's strategies and objectives. Furthermore, IT govemance integrates and institutionalizes good practices to ensure that the enterprise's IT supports the business objectives.

COBIT 4th Edition, Executive Summary, 2005 (0.6)
"KM Govemance involves a set of relationships and processes to direct and control the activities that amplify the utilization and the creation of knowledge. KM Govemance provides a framework through which the alignment of KM on the Corporate and IT strategies is achieved:

- when the KM approach is centered on information technologies, it is connected with the IT Govemance principles;

- when the KM approach is centered on the core business processes and the people, it is connected with the Corporate Govemance principles."

Fig. 4. KM Governance Perspective

we have to distinguish between the notion of KM Empirical Model that is a template, and the notion of KM System - a context dependant system, which is the implementation of this template in the real world (ref. Fig. 5).

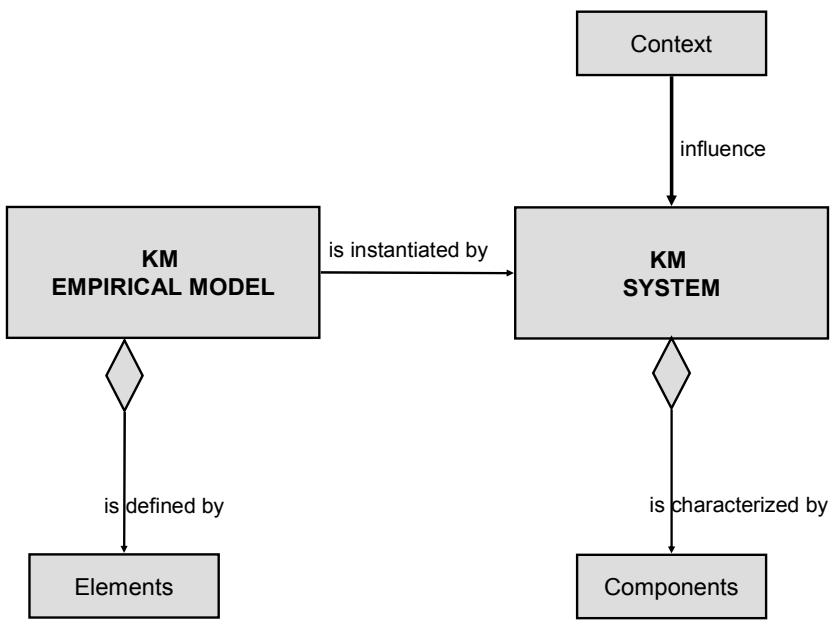

Fig. 5. KM Empirical Model and KM System 
To implement KMS components, Enterprises need a general model that is a pattern of reference (a template) in order to integrate KM Governance principles in their strategic vision, and to use $\mathrm{KM}$ as a factor that enable improving their efficiency and competitiveness. In this chapter, we refer to MGKME, our Model of General Knowledge Management within the Enterprise (Grundstein, 2005a, 2007, 2008) that articulates the enterprise's sociotechnical environment, the enterprise's value-adding processes, the managerial guiding principles specific to $\mathrm{KM}$ and the $A d-h o c$ infrastructures, the generic $\mathrm{KM}$ processes, and the organizational learning processes.

\subsection{The enterprise's sociotechnical environment}

E. Coakes (2002) defines sociotechnical approach as "the study of the relationships and interrelationships between the social and technical parts of any system" (p. 5). From KM viewpoint, the Socio-technical Environment constitutes the social fabric where autonomous individuals, supported by Information and Communication Technologies (ICT) and tangible resources, interact and are conversing through physical or virtual places (coffee machines, collaborative workspaces, weblogs, wikis, CoPs).

The socio-technical approach leads to emphasizing the link between knowing and action, with due regard to the basic constraints of the social system that is to give a sense to working time. Thus, KM initiative should result in Knowledge Management System (KMS) components that take into account the individuals, both as components and users of a system that allows them to be autonomous and to achieve their potentialities.

\subsection{The enterprise's value adding processes}

Value adding processes derive from the value chain described by Porter (1985) who identifies nine value-adding activities that he classifies into two main categories. The "primary activities" are: 1) in-bound logistics, 2) operations, 3) out-bound logistics, 4) marketing \& sales, and 5) Services. The "support activities" are: 1) business infrastructure, 2) human resource management, 3) technological development, and 4) supplies. In this way, Value-adding processes represent the organizational context for which knowledge is essential factors of performance. It is in this context that is implanted a $\mathrm{KM}$ initiative.

\subsection{The managerial guiding principles specific to KM and the Ad-hoc infrastructures}

The Managerial Guiding Principles should bring a vision aligned with the enterprise's strategic orientations, and should suggest a KM Governance principles by analogy with COBIT $^{\circledR}$. In particular, we established KM indicators. Numerous publications and books relates to that subject. From our viewpoint, we constructed two main categories of indicators in order to monitor a KM initiative: (i) a category of indicators that focus on the impacts of the initiative that favor enhancement of intellectual capital, (ii) a category of indicators that insure monitoring and coordination of $\mathrm{KM}$ activities, measuring the results, and insuring the relevance of the initiative.

In addition (ref. Fig. 6), we suggest a way to get a good articulation between the Deming's cycle PDCA (Deming,1982), and Argyris and Schön's Organizational learning (Argyris and Schön, 1996).

Firstly, we refer to the PDCA cycle of activities - plan, do, check, and act; this cycle well known as the Deming's Cycle by Quality Management practitioners, has inspired the ISO 9004 (2000) Quality Standards in order to get a continuous process improvement of the 
Quality Management System. Secondly, we refer to the Single-Loop Learning and Double-Loop Learning defined in the Argyris \& Schön's organizational learning theory

Furthermore, we should think about the Ad-hoc infrastructures, which are adapted sets of devices and means for action. Beyond a network that favors cooperative work, it is important to implement the conditions that will allow sharing and creating knowledge. An ad hoc infrastructure must be set up according to the specific situation of each company, and the context of the envisaged KM initiative. The SECI spiral of conversion Model proposed by Nonaka and Takeuchi (1995) and the Japanese concept of $B a$ inspire this infrastructure (Nonaka and Konno, 1998; Nonaka, Toyama, and Konno, 2000; Grundstein, 2011).

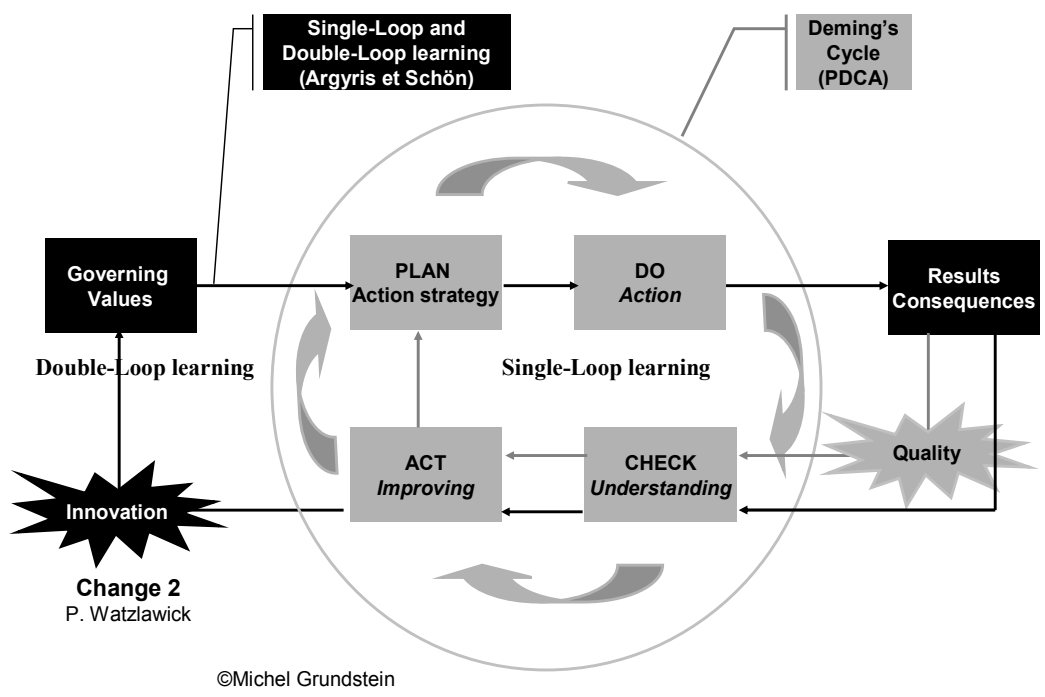

Fig. 6. Deming's cycle and Argyris \& Schön's Organizational learning

\subsection{The generic KM processes}

The generic KM processes answer the problem of capitalizing on company's knowledge defined in the following way (Grundstein, 1996) "Capitalizing on company's knowledge means considering certain knowledge used and produced by the company as a storehouse of riches and drawing from these riches interest that contributes to increasing the company's capital" (p. 141).

Several problems co-exist. They are recurring problems for a company. These problems constitute a general problematic that has been organized in five categories. Each of these categories contains sub-processes aimed to contribute a solution to the set of overall problems (ref. Fig. 7).

The Locating KM Process deals with the location of Crucial Knowledge, that is, Knowledge (explicit or tacit) that is essential for decision-making processes and for the progress of the support and value-adding processes. One can mention GAMETH ${ }^{\circledR}$ (Grundstein, 2000; Grundstein \& Rosenthal-Sabroux, 2004), an approach that provides the elements that lead to identifying the problems, clarifying the needs for knowledge, identifying and locating potential crucial knowledge, specifying the value-based assessment of this knowledge, and finally, determining "crucial knowledge". 
The Preserving Process deals with the retention of knowledge and skills. When knowledge can be articulated into words, it is necessary to acquire it with the bearers of knowledge, to represent it, to formalize it, and to conserve it. This leads to Knowledge Engineering activities notably described in (Schreiber et al, 2000). When knowledge cannot be articulated, then interactions through communities of practice or other types of networks must be encouraged.

The Enhancing Process deals with the benefit of knowledge and skills. It is necessary to make them accessible according to certain rules of confidentiality and safety, to disseminate them, to share them, to use them more effectively, to combine them, and to create new knowledge. Here is the link with innovation processes.

The Actualizing process deals with the actualization of knowledge and skills. It is necessary to appraise them, to update them, to standardize them and to enrich them according to the returns of experiments, the creation of new knowledge, and the contribution of external knowledge. Here is the link with business intelligence processes.

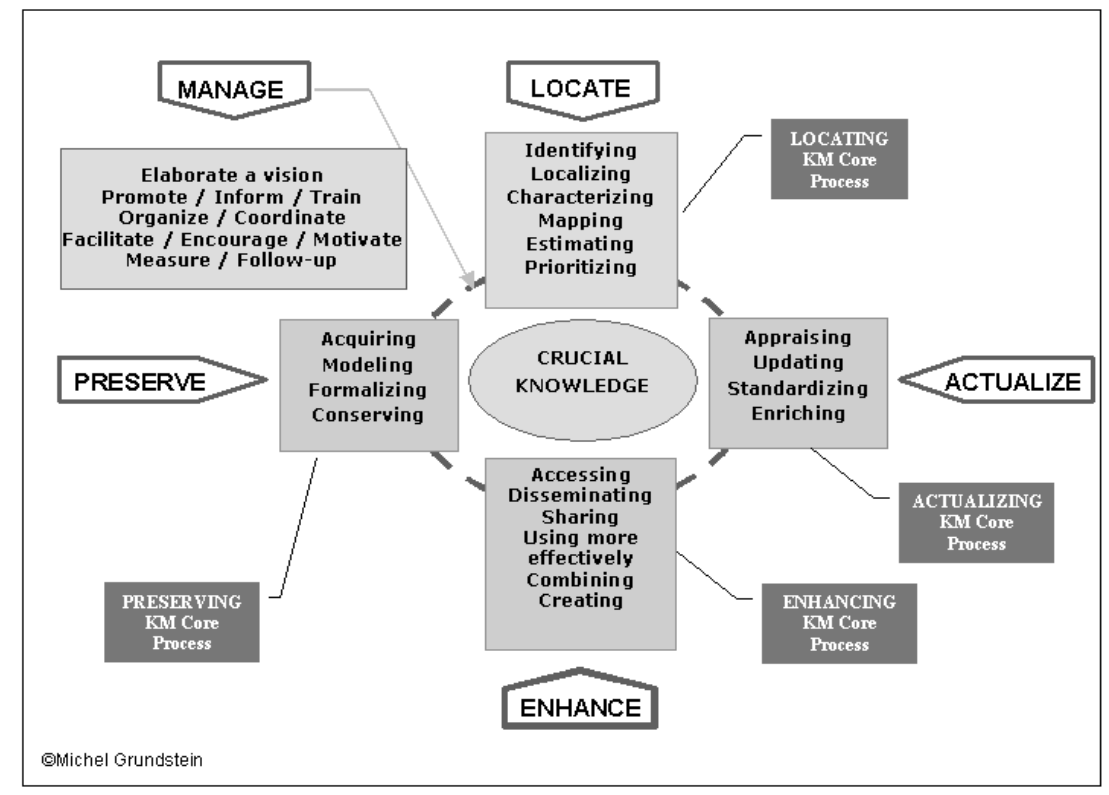

Fig. 7. The Generic KM Processes

\subsection{The organizational learning processes}

The Organizational learning processes underlay the whole generic KM processes. The aim of the organizational learning process is to increase individual knowledge, to reinforce competencies, and to convert them into a collective knowledge through interactions, dialogue, discussions, exchange of experience, and observation. The main objective consists in fighting against the defensive routines that make barriers to training and change. Therefore, it is a question of helping the members of the organization to change their way of thinking by facilitating an apprenticeship of a constructive way of reasoning instead of a defensive one. 


\subsection{MGKME description}

The MGKME, described hereafter (ref. Fig. 8), supports our full meaning of KM as defined in paragraph 4.2. It is an empirical model based both on our experience within the industry, and on our research works. MGKME rests on a Sociotechnical approach. It focuses on people and value adding processes. Moreover, the MGKME presents an attempt to articulate the Deming's Cycle PDCA and the Single-Loop Learning and Double-Loop Learning defined in the Argyris \& Schön's organizational learning theory. It suggests "ad hoc infrastructures" derived from the Nonaka and Takeuchi's SECI model and the Japanese concept of "BA". It highlights four generic KM processes (Grundstein, 2007): Locating crucial knowledge process; Preserving crucial knowledge process; Enhancing crucial knowledge process; and Actualizing crucial knowledge process.

MGKME is composed of two main categories of elements: (I) the underlying elements consist of (1) socio-technical environment and (2) value adding processes; (II) the operating elements focus on the underlying elements. They consist of (3) managerial guiding principles, (4) ad hoc infrastructures, (5) generic KM processes, (6) organizational learning processes, and (7) methods and supporting tools.

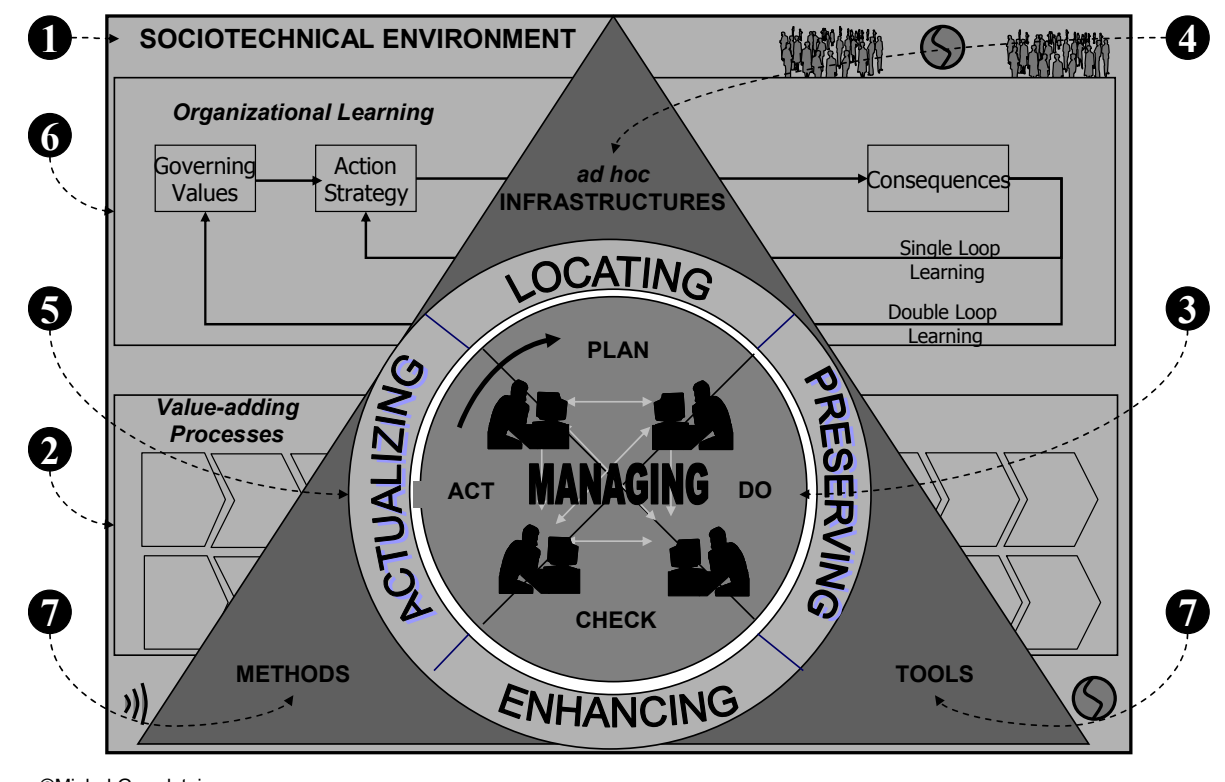

CMichel Grundstein

Fig. 8. Model for Global Knowledge Management within the Enterprise

Key Issues to address for every elements of each level are synthesized in Table 2 and 3.

Table 2 represents the underlying level of MGKME. The Underlying level of the MGKME contains the elements of MGKME that underlie the operating components of the Knowledge Management System. The core knowledge is embodied in people heads, and their abilities to utilize them and to generate new knowledge at the same 
time. The information technologies and the tangible technical resources enhance their competence, while value-adding processes and organizational infrastructures are structuring their activities. Nevertheless, their social interactions are essential factors, which leverage their potentialities, and that actually enable them to achieve effective results. Therefore, from our perspective, socio-technical environment( , and value-adding processes 2 are fundamental components of the Knowledge Management System.

\begin{tabular}{|c|c|c|}
\hline & Elements & Key Issues \\
\hline $\begin{array}{l}\text { I } \\
\text { U } \\
\text { N } \\
\text { D } \\
\text { E } \\
\text { R }\end{array}$ & $\begin{array}{l}\text { (1) } \\
\text { Sociotechnical } \\
\text { Environment }\end{array}$ & $\begin{array}{l}\text { Enterprise's Activities (sector, key value-chain elements, } \\
\text { geographical distribution, size, market, mass or batch } \\
\text { manufacturing processes, product lifecycle, oral or } \\
\text { written culture) } \\
\text { Relations and Interactions between ICT, Structure, and } \\
\text { People: their roles, their tasks } \\
\text { Capability to learn and Innovate } \\
\text { Social and Intellectual Capital Management Involvement }\end{array}$ \\
\hline $\begin{array}{c}\text { Y } \\
\text { I } \\
\mathrm{N} \\
\mathrm{G} \\
\text { LEVEL }\end{array}$ & $\begin{array}{l}\text { (2) } \\
\text { Value-adding } \\
\text { Processes }\end{array}$ & $\begin{array}{l}\text { Porter's Primary and Support Activities: } \\
\text { Running Processes } \\
\text { Business Processes } \\
\text { Design and Development Processes } \\
\text { Innovative Product and Services Processes }\end{array}$ \\
\hline
\end{tabular}

Table 2. MGKME's underlying Level

Table 3 represents the operating level of MGKME. The operating level of MGKME contains the elements of MGKME that focus on the underlying components of the Knowledge Management System, and consist of managerial guiding principles 3, ad hoc infrastructures $\boldsymbol{4}$, generic KM processes $\boldsymbol{6}$, organizational learning processes $\boldsymbol{\bullet}$, and methods and supporting tools for KM७.

\section{The enterprise's information and knowledge system (EIKS)}

The enterprise's information and knowledge system (EIKS) consists mainly in a set of individuals and digital information systems (ref. Fig. 9).

EIKS rests on a socio-technical context, which consists of individuals in interaction among them, with machines, and with the very EIKS. It includes:

- Digital Information Systems (DIS), which are artificial systems, the artefacts designed from information and communication technologies (ICT)

- An Information System (IS), constituted by individuals who, in a given context, are processors of data to which they give a sense under the shape of information. This information, depending of the case, is passed on, remembered, treated, and diffused by them or by the DIS. 


\begin{tabular}{|c|c|c|}
\hline $\begin{array}{l}\text { Model } \\
\text { Level }\end{array}$ & Elements & Key Issues \\
\hline \multirow[b]{2}{*}{$\underline{\text { II }}$} & $\begin{array}{l}\text { (3) } \\
\text { Managerial } \\
\text { Guiding } \\
\text { Principles }\end{array}$ & $\begin{array}{l}\text { Vision } \\
\text { KM Governance Principles (strategic alignment, } \\
\text { articulation between quality and organizational learning } \\
\text { management) } \\
\text { Main Development Axes } \\
\text { Indicators }\end{array}$ \\
\hline & $\begin{array}{l}\text { (4) } \\
\text { ad hoc } \\
\text { Infrastructures }\end{array}$ & $\begin{array}{l}\text { Content and Document Management Systems } \\
\text { Collaborative Information Systems } \\
\text { Organizational conditions encouraging interaction, } \\
\text { communication, and knowledge sharing }\end{array}$ \\
\hline \multirow{2}{*}{$\begin{array}{l}\mathrm{O} \\
\mathrm{P} \\
\mathrm{E} \\
\mathrm{R} \\
\mathrm{A} \\
\mathrm{T} \\
\mathrm{I} \\
\mathrm{N} \\
\mathrm{G}\end{array}$} & $\begin{array}{l}\text { (5 } \\
\text { Generic KM } \\
\text { Processes }\end{array}$ & $\begin{array}{l}\text { Locating Process } \\
\text { Preserving Process } \\
\text { Enhancing Process } \\
\text { Actualizing Process } \\
\end{array}$ \\
\hline & $\begin{array}{l}6 \\
\text { Organizational } \\
\text { Learning } \\
\text { Process }\end{array}$ & $\begin{array}{l}\text { Team Learning Processes } \\
\text { New Organizational Structures Experiments } \\
\text { General Vision, and Systemic Approach } \\
\text { Routines (defensive or constructive) } \\
\text { Knowledge Dissemination } \\
\text { Constant Evolution versus Change ( Alter, 2000) }\end{array}$ \\
\hline LEVEL & $\begin{array}{l}\text { Methods and } \\
\text { Supporting } \\
\text { Tools }\end{array}$ & $\begin{array}{l}\text { General Methods and Tools } \\
\text { Knowledge Engineering, Artificial Intelligence (Semantic } \\
\text { WEB and Ontology) } \\
\text { CSCW -Computer Supported Cooperative Work (Multi- } \\
\text { agents Systems) } \\
\text { Social Networks (Identification, Visualization, and } \\
\text { Informal Social Network Analysis Systems) } \\
\text { Impact of Web } 2.0\end{array}$ \\
\hline
\end{tabular}

Table 3. MGKME's operating Level

- A Knowledge System (KS), consisting of tacit knowledge embodied by the individuals, and of explicit knowledge formalized and codified on any shape of supports (documents, video, photo, digitized or not). Under certain conditions, digitized knowledge is susceptible to be stored, processed and spread with the DIS. In that case, knowledge is no more than information.

We insist on the importance to integrate the individual as a component of the system. In fact, relying to our assumptions, we argue that knowledge resides primarily in the heads of individuals, and in the social interactions of these individuals. Knowledge is dependent of the individual's interpretative frameworks, and the context of his action. Consequently, as mental models and interpretative frameworks are directly forged by cultural factors, it induces to stress the role of cultural factors when social interactions, information sharing and knowledge transfer are essential to enable efficiency in the global economy. Here, knowledge transfer 
must be understood as transmission, plus absorption and use of knowledge (Davenport and Prusack 1998 p.101). Therefore, the project manager should consider the individual (knowledge worker and decision-maker) both at once as a user, and a component of the EIKS. In EIKS, the information and knowledge portals have become essential for the knowledge workers who have to share with colleagues disseminated all around the world.

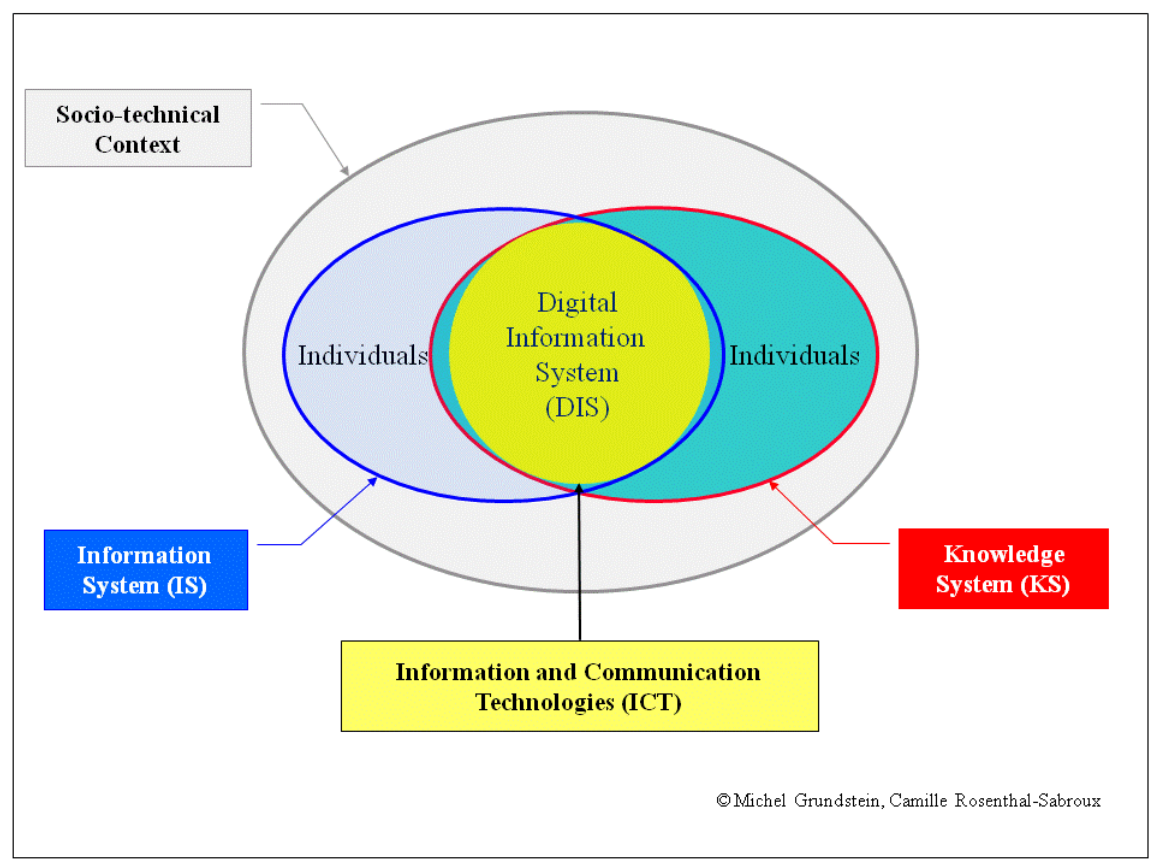

Fig. 9. The enterprise' information and knowledge system (EIKS)

\section{A well-balanced KM initiative strategy within organizations}

A general KM initiative shows willingness, at the highest level of the enterprise, to encourage all the steps, and to implement all the means leading to capitalize on knowledge to pull strategic advantages of it. Afterwards, we refer to our own studies about general KM initiative (Grundstein, 2005b).

There exist three main development phases: (i) The Strategic Orientation Phase which aim is to establish KM Initiative outline and agenda; (ii) Operational Management Phase which aim is to design and specify specific projects linked to capitalizing on knowledge problems; and (iii) Projects Deployment Phase which aim is to monitor and implement EIKS. For the purpose of this chapter, we will focus on the first phase, the strategic orientation phase.

\subsection{Strategic orientation phase}

The strategic orientation phase of general KM initiative leads to establish KM initiative outline and agenda, taking into account priorities and available resources. It includes four steps (ref. Fig. 10): (i) Elaborating the Enterprise's KM Vision; (ii) Aligning KM Strategy on 
Enterprise's Strategies; (iii) Monitoring KM Maturity Study; and (iv) Establishing KM Initiative Program. Questions which must be considered focus notably on achieving alignment of the KM strategy on the organization's strategy:

- How to articulate the general KM initiative with the Enterprise's strategic orientations?

- How to make the Enterprise's members, whatever are their hierarchical level, aware of KM interest for them, and the Enterprise?

- How to assess the Enterprise's KM maturity and its capacity to implement KM projects?

- How to identify IS needs, KS needs, and EIKS needs?

- How to define the KM initiative outline, and the agenda?

- What are predictable impacts?

- How to gather constructive conditions?

- What are the activities to develop and promote?

- What are the indicators to set up?

- How to establish Ad-hoc organizational structures, and to attribute roles to stakeholders?

- How to create and support organizational learning processes leading towards more information sharing, and knowledge transfer?

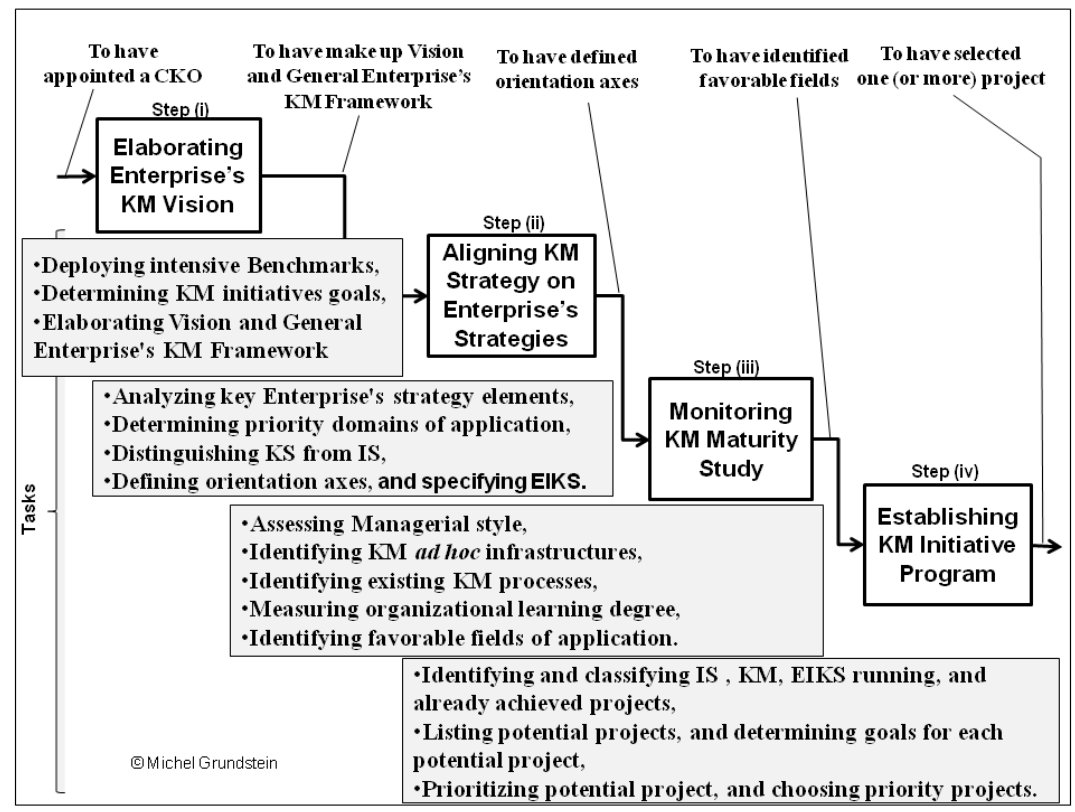

Fig. 10. The Strategic Orientation Phase

The strategic orientation phase is crucial and can avoid getting KM resources outcomes unused. We argue that, most of time, IT approach leads confusing notions of information and knowledge, and misunderstanding the goals: do we have to develop an Information System or do we have to implement an EIKS that integrate people as users and components of the system? Therefore, the strategic orientation phase must help to build a general KM vision that makes a clear distinction between technology as a support to share individual's tacit knowledge, and 
technology as a means to collect, store, and distribute explicit and codified knowledge that is no more than information. Beyond benchmarking studies, to deal with the strategic orientation phase, Enterprises need a Meta model that is a pattern of reference (a template) in order: (i) to integrate KM Governance principles; (ii) to adapt it to their own situation; (iii) to monitor KM Maturity study (Grundstein, 2008, p. 424); and (iv) to envision integrating Information systems and KM systems in the same both digital and human system that we call EIKS.

\section{Conclusions and perspectives}

Most of time, the positivist paradigm of KM thought as a means to acquire, codify, store and disseminate knowledge, considers knowledge as an object, and so disregards the importance of individual's tacit knowledge used in action. Although this paradigm of KM is greatly shared, without awareness when elaborating KM initiative's strategy, we can confuse the notions of information and knowledge. The constructivist paradigm of KM proposed in this paper is founded on the DITEK process model, and three postulates. It brings an open definition of KM focused on the activities and processes that enhance the utilization and the creation of knowledge within organizations; in doing so, it induces a well-balanced technological, managerial and socio-technical KM initiative strategy. Therefore, to avoid misunderstanding during the strategic orientation phase of a KM initiative, we pointed out that it was fundamental to clearly distinguish the notion of information from the notion of knowledge.

The three postulates that change the paradigm of KM induce an open definition of KM that leads to integrate the whole dimensions that should be involved in a KM initiative. They induce a specific KM governance, and lead towards a technological, managerial, and sociotechnical well-balanced KM initiatives within organizations referring to general model for knowledge management within organization so called MGKME. Furthermore, distinguishing Information from Knowledge opens our mind on a different view of information systems: these systems based on Digital Information System (DIS) integrate people, both at the same time, as users and components of the system. This pragmatic vision needs thinking about the architecture of an Enterprise's Information and Knowledge System (EIKS), which must be a basis of discussion during the strategic orientation phase of a general KM initiative.

\section{Acknowledgement}

This work is dedicated to Dany my wife. With her dynamism, joie de vivre, love and trust towards me, she always supported and encouraged me to go ahead in my works and my researches, making the conditions allowing us to live with a complete peace of mind.

I am grateful to Camille Rosenthal Sabroux who gave me the opportunity to collaborate with Paris Dauphine University, and all the students whose continuous contribution and relevant questioning encouraged me to clarify and improve the models.

\section{References}

Alter, N. (2000) L'innovation ordinaire. Paris:France Presses Universitaires de France.

Amin, A., Cohendet P. (2004) Architectures of Knowledge, firms, capabilities, and communities. New York US: Oxford University Press Inc.

Argyris, C., Schön, D.A. (1996) Organizational Learning II. Theory, Method, and Practice. Readings, MA: Addison-Wesley Publishing Company. 
CEN-CWA 14924-1 (2004). Knowledge Management Framework. In European Guide to Good Practice in Knowledge Management (Part 1). Brussels: CEN, CWA 14924-1:2004 (E). Retrieved June 19, 2004, from ftp://cenftp1.cenorm.be/PUBLIC/CWAs/eEurope/KM/CWA14924-01-2004-Mar.pdf

Coakes, E. (2002) Knowledge Management: A Sociotechnical Perspective. In E. Cokes, D. Willis \& S. Clarke (Eds), Knowledge Management in the Sociotechnical World (Chapter 2, pp.4-14). London, Springer-Verlag.

COBIT $^{\circledR}$ (2005) Control Objectives for Information and Related Technology. Control Objectives, Management Guidelines, Maturity Models, (4th Edition). Rolling Meadows Illinois: IT Governance Institute.

Davenport T. H., Prusak L. (1998) Working Knowledge. Harvard Business School Press, Boston.

Deming, W.E. (1982): Out of the Crisis. MIT Press International

Edvinsson, L. \& Malone, M. S. (1997). Intellectual Capital. Realizing your Company's True Value by Finding its Hidden Brainpower. New York, NY: HarperCollins Publisher, Inc.

Grundstein, M. (1996). "CORPUS", an Approach to Capitalizing Company Knowledge. P. Ein-Dor (Ed.) Artificial Intelligence in Economics and Management (pp.139-152). Tel-Aviv, Boston, MA: Kluwer Academic Publisher.

Grundstein, M. (2000). From capitalizing on Company's Knowledge to Knowledge Management. In D. Morey, M. Maybury, \& B. Thuraisingham (Eds), Knowledge Management, Classic and Contemporary Works (chapter 12, pp. 261-287). Cambridge, Massachusetts: The MIT Press.

Grundstein, M. (2005a). MGKME: A Model for General Knowledge Management within the Enterprise. 2nd International Conference on Intellectual Capital, Knowledge Management and Organizational Learning, Proceedings. American University in Dubai, UAE, (ICICKM05 Proceedings pp.201-211). Reading, UK: ACL.

Grundstein M. (2005b) Pilotage d'un projet Global de Knowledge Management (PGKM). Research Report \#12. Paris, France: MG Conseil (www.mgconseil.fr ).

Grundstein M. (2007) Knowledge Workers as an Integral Component in Global Information System Design. In Wai K. Law (Ed.), Information Resources Management: Global Challenges (Chapitre XI, pp. 236-261). Hershey PA: Idea Group Publishing, 2007.

Grundstein, M. (2011) Establishing an Ad Hoc Infrastructure for Innovative Technologies Deployment: The Case of Knowledge-Based Systems. In E.N. Murthy (Ed.), The IUP Journal of Infrastructure, Vol. IX No. 2, Andhra Pradesh: India: The Icfai University Press.

Grundstein, M. (2008) Assessing the Enterprise's Knowledge Management Maturity Level. Int.J. Knowledge and Learning, Vol.4, No. 5, pp. 415-426.

Grundstein M., Rosenthal-Sabroux C. (2003) Three Types of Data For Extended Company's Employees: A Knowledge Management Viewpoint. In M. Khosrow-Pour (Ed.), Information Technology and Organizations: Trends, Issues, Challenges and Solutions, 2003 IRMA Proceedings (pp. 979-983). Hershey, PA: Idea Group Publishing.

Grundstein, M., \& Rosenthal-Sabroux, C. (2004). GAMETH®, A Decision Support Approach to Identify and Locate Potential Crucial Knowledge. In D. Remenyi (Ed.), Proceedings 5th European Conference on Knowledge Management (pp. 391 - 402). Reading, UK: Academic Conferences Limited.

Guldentops, E. (2004). Governing Information Technology through COBIT®. In W. V. Grembergen (Ed.), Strategies for Information Technology Governance (chap. XI, pp. 269-309). Hershey, PA: Idea Group Inc. 
Haeckel, S., H. (2000) Managing Knowledge in Adaptive Enterprises. In C. Despres and D. Chauvel (Eds), Knowledge Horizons (chap. 14, pp. 287-305). Woburn, MA: Butterworth-Heinemann.

Kautz, K., Kjaergaard, A. (2008) Knowledge Sharing in Software Development. In P. A. Nielsen and K., Kautz (Eds), Software Processes \& Knowledge. Beyond Conventional Software Process Improvement (Chapter 4, pp.43-68). Aalborg, Denmark: Software Innovation Publisher, Aalborg University.

Laudon K C, Laudon J P. (2006) Management Information Systems; Managing the Digital Firm. Upper Saddle River, New Jersey: Pearson Education, Inc, (Ninth edition).

Muller, H. \& Maasdorp, C. (2011) The data, information, and knowledge hierarchy and its ability to convince. Fith International Conference on Research Challenges in Information Science, Gosier, Guadeloupe, France, RCIS proceeding

Nelson, R.R., \& Winter, S.,G. (1982) An Evolutionary Theory of Economic Change. Cambridge, MA: Harvard University Press.

Nonaka, I., Konno, N. (1998) The Concept of "Ba": Building a Foundation for Knowledge Creation. California Management Review, spring 1998, Vol. 40 No. 3, 40-54.

Nonaka, I., Takeuchi, H. (1995) The Knowledge Creating Company. New York: Oxford University Press

Nonaka, I., Toyama, R., Konno, N. (2000) SECI, Ba and Leadership: a Unified Model of Dynamic Knowledge Creation.Long Range Planning 33, 5-34. Elsevier Science Ltd

O'Dell, C. and Hubert, C. (2011) The New Edge in Knowledge, How Knowledge Management is Changing the Way we Do Business. APQC, Hoboken, New Jersey: John Wiley \& Sons.

OECD (2004). OECD Principles of Corporate Governance. Retrieved September, 2005, from http://www.oecd.org/document/49/0,2340,en_2649_34813_31530865_1_1_1_1,00. htmlPolanyi, M. (1966) The Tacit Dimension. London: Routledge \& Kegan Paul.

Polanyi, M. (1966). The Tacit Dimension. London: Routledge \& Kegan Paul.

Porter, M. E. (1985) Competitive Advantage: Creating and Substaining Superior Performance. New York: The Free Press.

Rowley, J. (2007) The Wisdom hierarchy: representations of the DIKW hierarchy. Journal of Information Science, 33 (2), pp. 163-180. Retrieved from http://jis.sagepub.com/cgi/content/abstract/33/2/163

Schreiber, A.Th., Akkermans, J.M., Anjewierden, A.A., de Hoog, R., Shadbolt, N.R., Van de Velde, W., \& Wielinga, B.J. (2000). Knowledge Engineering and Management. The CommonKADS Methodology. Cambridge, Massachusetts: The MIT Press.

Sena J.A., Shani A.B. (1999) Intellectual Capital and Knowledge Creation: Towards an Alternative Framework. In J. Liebowitz (Ed.), Knowledge Management Handbook (chapter 6, pp. 6.1-6.29). Boca Raton, Florida: CRC Press LLC.

Snowden, D. (2000) The Social Ecology of Knowledge Management. In C. Despres \& D. Chauvel (Eds) Knowledge Horizons (chap. 12, pp. 237-365). Woburn, MA: Butterworth-Heinemann.

Takeuchi H., Nonaka, I. (2000) Theory of Organizational Knowledge Creation. In D. Morey, M. Maybury, B. Thuraisingham (Eds), Knowledge management, Classic and Contemporary Works (Chapter 6, pp. 139-182). Cambridge, MA: The MIT Press.

Tsuchiya S. (1993) Improving Knowledge Creation Ability through Organizational Learning. ISMICK'93 Proceedings, International Symposium on the Management of Industrial and Corporate Knowledge, UTC, Compiègne.

Wiig, K., 2004. People-Focused Knowledge Management: How Effective Decision Making Leads to Corporate Success. Burlington, MA: Elsevier Butterworth-Heinemann. 


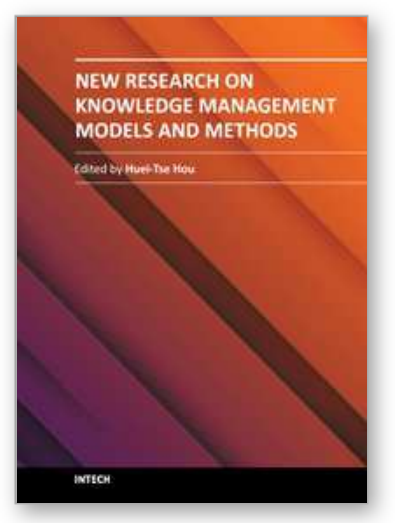

\author{
New Research on Knowledge Management Models and Methods \\ Edited by Prof. Huei Tse Hou
}

ISBN 978-953-51-0190-1

Hard cover, 426 pages

Publisher InTech

Published online 23, March, 2012

Published in print edition March, 2012

Due to the development of mobile and Web 2.0 technology, knowledge transfer, storage and retrieval have become much more rapid. In recent years, there have been more and more new and interesting findings in the research field of knowledge management. This book aims to introduce readers to the recent research topics, it is titled "New Research on Knowledge Management Models and Methods" and includes 19 chapters. Its focus is on the exploration of methods and models, covering the innovations of all knowledge management models and methods as well as deeper discussion. It is expected that this book provides relevant information about new research trends in comprehensive and novel knowledge management studies, and that it serves as an important resource for researchers, teachers and students, and for the development of practices in the knowledge management field.

\title{
How to reference
}

In order to correctly reference this scholarly work, feel free to copy and paste the following:

Michel Grundstein (2012). Three Postulates That Change Knowledge Management Paradigm, New Research on Knowledge Management Models and Methods, Prof. Huei Tse Hou (Ed.), ISBN: 978-953-51-0190-1, InTech, Available from: http://www.intechopen.com/books/new-research-on-knowledge-management-modelsand-methods/three-postulates-that-change-knowledge-management-paradigm

\section{INTECH}

open science | open minds

\author{
InTech Europe \\ University Campus STeP Ri \\ Slavka Krautzeka 83/A \\ 51000 Rijeka, Croatia \\ Phone: +385 (51) 770447 \\ Fax: +385 (51) 686166 \\ www.intechopen.com
}

\author{
InTech China \\ Unit 405, Office Block, Hotel Equatorial Shanghai \\ No.65, Yan An Road (West), Shanghai, 200040, China \\ 中国上海市延安西路65号上海国际贵都大饭店办公楼 405 单元 \\ Phone: +86-21-62489820 \\ Fax: +86-21-62489821
}


(C) 2012 The Author(s). Licensee IntechOpen. This is an open access article distributed under the terms of the Creative Commons Attribution 3.0 License, which permits unrestricted use, distribution, and reproduction in any medium, provided the original work is properly cited. 